\title{
NARRATIVAS INCONCLUSAS: LISBOA NA PENA DE FOLHETINISTAS de finals do SÉc. Xix (FIalho de Almeida e GeRVÁsio LOBATO)
}

Manuel Ferro*

ferro@fl.uc.pt

Resumo: A imagem de Lisboa, que se colhe das vivências urbanas objecto de tratamento literário nos folhetins do fim-de-século XIX, tanto conduz à desmontagem dos códigos de valores dominantes, como a uma visão poética de uma cidade, capital de Reino e de Império, decadente, sem conseguir acompanhar o ritmo do progresso das grandes capitais europeias. Através da análise de folhetins de diferente índole de Fialho de Almeida e Gervásio Lobato, focam-se os aspectos que mais impressionaram os autores e, necessariamente, os leitores da época, mostrando igualmente como se inserem na tradição de um género que antes contou com nomes tão ilustres como o de Júlio César Machado.

Palavras-Chave: Folhetim, imagens literárias da cidade, Fialho de Almeida, Gervásio Lobato, Fim-de-século.

O FOLHETIM OITOCENTISTA E O REGISTRO DA VIDA URBANA

Considerando que o folhetim é um modo de escrever a História, de modo fragmentário, bem entendido, mas nem por isso de maneira

\footnotetext{
* Doutor em Literatura Comparada pela UC. Professor Auxiliar na Universidade de Coimbra.
} 
muito diferente em termos de procedimento e abordagem dos comentários, epanáforas, anedotas, memórias, relações, biografias, fastos ou até anais, o certo é que dedicam particular atenção ao acontecimento efémero (RODRIGUES, 2003, p. 3), ao pitoresco, retomando traços e inserindo-se na linha da crónica jornalística. Por esse motivo Ernesto Rodrigues tece a genealogia do folhetim, recuando às crónicas medievais, muito embora saliente a importância da reconfiguração dos códigos do género no século XVIII quando a imprensa assistiu a uma verdadeira explosão, quer em termos de produção, quer de popularidade. Ao referir o proémio do Portugaliae Monumenta Historica. Scriptores, I, acentua o facto de o relato ser "renenbrança" [ ], isto é, lembrança, memória, logo, dentro do falível e do subjectivo, os textos coetâneos jogam-se na tensão entre o processo e o método historiográficos, a situação de narrador com voz própria e os ares do tempo. A parcialidade não será extravagância no século do florescimento da imprensa, quando nascem títulos como facções partidárias, literárias, etc." (RODRIGUES, 2003, p. 6).

No século XIX, o leque dos assuntos preferenciais amplia-se e além da bibliografia e teatro, a viagem, como matéria, tema, pretexto ou cenário, passa a assumir uma importância crescente no folhetim, à medida que este vai adquirindo identidade própria e se distingue da crónica. Apesar de Almeida Garrett já distinguir estes dois tipos de textos e as convulsões da sociedade portuguesa em meados do século contribuírem para a afirmação deste novo tipo de registo jornalístico, nem sempre as fronteiras entre ambos são assim tão fáceis de identificar. Eça de Queirós, ao dissertar sobre a crónica, no Distrito de Évora, assevera:

A crónica como que a conversa íntima, indolente desleixada, do jornal com os que a lêem: conta mil coisas, sem sistema, sem nexo; espalha-se livremente pela natureza, pela vida, pela literatura, pela cidade; fala das festas, dos bailes, dos teatros, das modas, dos enfeites, fala em tudo, baixinho, como se faz ao serão, ao braseiro, ou ainda de Verão, no campo, quando o ar está triste. Ela sabe anedotas, segredos, histórias de amores, crimes terríveis; espreita porque não lhe fica mal espreitar. Olha para tudo, [...], a crónica tem uma doidice jovial, tem um estouvamento delicioso: confunde tudo, tristezas e facécias, enterros e actores ambulantes, um poema moderno e o pé da imperatriz da China; ela conta tudo o que pode interessar pelo espírito, pela beleza, pela mocidade; ela não tem opiniões, não sabe do resto do jornal; [...] não tem a voz grossa da política, nem a voz indolente do poeta, nem a voz doutoral do crítico [...]. (Distrito de Évora, n. 1, de 6-1-1867). 
$\mathrm{Na}$ realidade, quanto Eça afirma pode ser aplicado ao folhetim dos jornais do seu tempo. Como factor de diferenciação, a crónica adquire um traço mais combativo e interventivo, transformando-se, face ao tipo de jornalismo praticado, o que a caricatura é para a pintura, ferindo a rir, desrespeitando tudo e todos, fazendo uso do escárnio e do ridículo ${ }^{1}$. No entanto, alguma tentativa de dilucidação dos conceitos aparece quando o mesmo autor afirma:

[...] Nós vamos atravessando uma época em que a crónica pouca importância tem: a importância e a consideração, e a atenção, vão segundo as épocas, duma a outra secção dos jornais: hoje o folhetim, amanhã o artigo de fundo, depois a crónica, depois os anúncios [...]. (Distrito de Évora, n. 5, 20-1-1867)

E apesar da afirmação do folhetim, muito particularmente do folhetimromance ou folhetim-série, constituir uma verdadeira revolução em termos jornalísticos, os folhetins-crónica continuam a ser o espaço de eleição para aí se construírem os retratos das mais variadas facetas que a vida urbana da capital proporciona em cada recanto, cada vez mais com a ideia de se estar a fixar um momento, com a peculiaridade da câmara fotográfica, que o inexorável fluir do tempo em breve acabará por extinguir. Não é por acaso que as vivências de fim de século aí surgem delineadas com um profundo sentimento, um olhar poético e até já uma inalienável nostalgia, saboreandose aqueles últimos momentos de uma realidade que a curto prazo acabará por desaparecer. Daí também o hedonismo que perpassa das páginas do folhetim finissecular e justifiquem o interesse manifestado pelo fait divers da sociedade alfacinha. Por isso Santos Gonçalves, ainda a propósito da crónica, n' O Recreio, de 6-9-1886, afirma:

As crónicas deviam ser, como os exercícios venatórios, proibidas em certa época do ano. S. Carlos fechado, crónica interrompida até fins de Setembro ou princípio de Outubro.

Porque a verdade é que, ao perderem-se no espaço as últimas vibrações da ópera italiana, as andorinhas das salas e as avestruzes da política logo cuidam de emigrar para onde os ares são mais puros e mais frescos, e Lisboa, reduzido à soporífera pacatez de uma cidade de província, fornece apenas aos seus cronistas... a sensaboria e o calor, obrigando-os a lançar mão, para entreterem os leitores, do triste privilégio de maçar e dizer banalidades, coisa que, antes de desenvolvida a cronicomania, parecia ser um dos atributos da liberdade poética, a muleta redentora de quase todas as tolices obrigadas a verso. 
O Recreio. Revista semanal literária e charadística, 2. ${ }^{a}$ Série, n. ${ }^{\circ} 4$, 6-9-1886, p. 49-50)

Contudo, com o ritmo dos tempos, mudam-se igualmente as técnicas de composição deste tipo de textos, e de modo mais evidente com a introdução do uso do folhetim, como afirmámos. E esse fenómeno torna-se a tal ponto sensível, que D. José Carcomo o aborda na mesma revista, em 25-10-1886:

Em tempos que já lá vão - tempos saudosos para os talentos medíocres -, fazer uma crónica para um jornal desta índole não era das coisas mais difíceis. Durante a semana, o cronista ia uma ou duas vezes ao teatro, frequentava uma certa roda, lia o último romance ou o último almanaque e depois só tinha o trabalho de expor o que lera ou de narrar o que vira.

Com duas transcrições e três elogios, estava feita a crítica literária; com uma dúzia de personagens que entravam nas comédias ou nas contradanças, estava elaborada a revista teatral e elegante.

Era um maná.

Hoje, fia mais fino." (O Recreio. Revista semanal literária e charadística, 2. Série, n. 11, 25-10-1886, p. 161-163)

E, por isso, define-se o que os novos tempos e o gosto dominante esperam de uma crónica:

A crónica, portanto, em hebdomadários nitidamente independentes, despreocupados das convenções sociais, a que dão diversos títulos, mais ou menos pomposos, mais ou menos insidiosos; a crónica de um periódico puramente literário deve ser alegre, expansiva, muito sincera; deve ter harmonias gratas aos mais castos ouvidos, perfumes agradáveis aos olfactos mais delicados, tocar de leve e graciosamente em factos que as leis não previnem, saltitar de ramo em ramo, como as aves, pousar de flor em flor, como as mariposas. Deve ser isto a crónica moderna. (O Recreio. Revista semanal literária e charadística, 2. ${ }^{a}$ Série, n. ${ }^{\circ} 11,25-10-1886$, p. 163$)$

Com a proliferação e popularidade crescente do folhetim, fenómeno que colocaríamos em termos de 'especialização' do folhetinista face ao cronista, compreende-se a razão pela qual o estatuto do autor se altera no período em que se operam as mudanças no género e que Ernesto Rodrigues regista do seguinte modo: 
[...] $\mathrm{O}$ folhetinista nasce de fora para dentro: precisa de um ainda que breve passado convincente na literatura; o cronista - em princípio, redactor obscuro - vai, nessas eras, de dentro (às vezes, desce ao folhetim, como se dará com António Augusto Teixeira de Vasconcelos, na sua Gazeta de Portugal) para fora, tornando-se conhecido (RODRIGUES, 2003, p. 15).

Mas com a estética dominante do Positivismo, que proporciona as bases teóricas do Realismo e do Naturalismo, a representação do espaço geográfico e social ganha alento e uma nova revalorização dentro do campo da produção literária. O folhetim, ao dedicar particular atenção aos aspectos típicos da nação, às peculiaridades da cultura popular, aos costumes da época, aos usos populares contribui de modo sensível para a representação do país que somos, tornando-se também numa via de acesso privilegiada ao estudo da História do nosso povo e da nossa cultura, mesmo quando o tema é o vazio de assunto, como defende Luís Augusto Palmeirim, n’ A Voz de Setembro, em 8-7-1862:

O folhetinista português é talvez o primeiro escritor do século. Meio moralista e meio cortesão, só lhe é permitido ocupar-se dos assuntos que o público aceitou: não havendo assunto quase nunca, cumpre-lhe tratar semanalmente de coisa nenhuma.

Uma coisa é certa: a partir de meados do século XIX, o folhetim tornase indispensável na imprensa periódica e até quotidiana. Nele se delineia o retrato de uma nação, a História de um País e a de um Povo. É verdade que a História pátria cedia lugar à História da sociedade. As figuras e as paisagens da província também lá aparecem tratadas, mas são, sem dúvida alguma, os horizontes da paisagem urbana, sobretudo lisboeta ou portuense que predominam e se impõem no interesse e na escrita do folhetinista. As vivências urbanas de uma cidade como Lisboa, ainda sem a euforia e os aliciantes de uma capital europeia como Paris, Londres ou Berlim, permitem o registo de uma rotina que é possível rastrear a cada hora que passa, desde o canto do galo ao alvorecer até ao cair das trevas nos recantos menos favorecidos dos bairros pobres. E mesmo assim, todo o momento é saboreado com intensidade poética. Era dominante a consciência de que aquele estado de coisas estava condenado a desaparecer. Por isso, o elogio da cidade se verifica, mesmo quando o assunto tratado é a denúncia da miséria e das deficientes condições de vida das camadas mais desfavorecidas. Um halo de fascínio ressalta das páginas de autores como Fialho de Almeida 
ou Gervásio Lobato. As suas obras bem se podem inserir na sequência das laudes urbium, como delineámos em "Narrativas inconclusas: Vislumbres de Lisboa no romance-folhetim de meados do Séc. XIX (Lisboa de Ontem, de Júlio César Machado)" (FERRO et al, 2010), centrando-nos, na altura, em A Vida em Lisboa, de Júlio César Machado.

Por todos os motivos referentes ao género aí apontados e pelo facto de os autores aqui considerados se terem afirmado no campo da produção literária fundamentalmente como folhetinistas, mas também como romancistas ou dramaturgos, não pretendemos estabelecer uma divisão intransponível entre os 'folhetins-crónica' e os 'folhetins-série' por eles assinados, quando forem tratados os respectivos aspectos que se referem à representação da vida lisboeta de fins do século XIX. No entanto, das obras objecto de análise, poder-se-á adiantar que Lisboa em Camisa (1890), de Gervásio Lobato, tal como acontece com A Vida em Lisboa. Romance contemporâneo (1853), de Júlio César Machado, se inserem mais no filão do folhetim-série, e Lisboa Galante (1890), de Fialho de Almeida, ou A Comédia de Lisboa (1911), igualmente da autoria de Gervásio Lobato, partilham predominantemente das características do folhetim-crónica.

\section{IMPRESSÕES DA PASSAGEM DO TEMPO NUMA LISBOA DE ANTANHO}

Um exemplo representativo de folhetins da geração situada mais próximo da viragem do século constitui o conjunto de textos reunidos no volume intitulado Lisboa galante, de Fialho de Almeida ${ }^{2}$. Se algum elo de ligação se pode identificar que os possa articular entre si, esse elemento devese reconhecer no plano temático, visto que a todos eles subjaz a preocupação em caracterizar a variegada componente humana da sociedade lisboeta. José Valentim Fialho de Almeida, apesar de se ter formado em Medicina, foi através da carreira das letras que se consagrou. Além de contista de reconhecidos méritos, foi eminente colaborador de inúmeros jornais e revistas, destacando-se como mordaz crítico de arte e de costumes. Os seus textos literários e folhetins traduzem bem a virulência do crítico e a sensibilidade do artista numa busca constante e insistente de um ideal de perfeição. Da experiência de vida dos períodos que passa em Lisboa, resultam as composições que reúne no volume aqui objecto de análise - Lisboa Galante. O seu olhar estetizante transmite a imagem fiel e realista de uma cidade, em que se cruzam diferentes vectores e vivências distintas: da velha Lisboa barroca de casta, em vias de extinção, aos bairros novos da burguesia liberal fontista; dos exteriores algo decadentes, aos interiores tépidos e confortáveis. Nesse 
cenário deambulam os habitantes de bela aparência e saudável apresentação, os polícias, viscondes e vagabundos, criadas e 'galegos'. Contudo, neste retrato delicadamente esboçado, a pena de Fialho de Almeida distingue-se pela esmerada representação do gradual passar das horas em ambiente urbano, resultando daí uma subtil aguarela de impressões captadas com elevada sensibilidade.

Às vezes, o panorama observado permite o salto para o devaneio, para a recordação, cedendo a voz à nostalgia do passado, na tentativa de reconstituir uma paisagem urbana através de imagens que persistem em não desaparecer.

Eu ainda conheci um pouco da Lisboa antiga, como ela teria sido no tempo do Sr. D. João VI, e conforme Beckford a aguarelou nas suas Memórias. Cidade de frades, beatas e desembargadores, soturna de noite, reentrando em becos onde os gatos se moviam num sabbat fosforescente, com lendas de fadistas que enchiam a província de pânico e de epilepsia a prosa dos jornais; e tavernas onde noite e dia o gás flambava, nimbando a fumarada dos cachimbos. Nos bairros de residência, retraídos sobre as encostas das sete colinas; nos pequenos largos onde seis árvores davam sombras pavorosas de emboscados; em cada íngreme ruela corcovando bruscamente por baixo dum arco, onde o braço dum lampião ressaía do granito, mal-humorado por alumiar os lameiros da via - prédios altos, estreitos, irregulares, coifados de mansardas sem vidros, encostavam-se uns aos outros, rindo sardonicamente pela boca dos portais sem portas, e ressaindo como ébrios das linhas geométricas de construção - em todas as sacadas havia roupa a enxugar, nespereiras em caixões - e jardins de pequenos empregados bucólicos pesavam sobre as varandas decrépitas, onde algum gato reflectia o nada das cousas mundanas, e uma mulher verde espulgava cobertores. Em baixo, as lojas de venda, pintadas uma só vez em vida dos lojistas, ofereciam ignóbeis detalhes dos géneros acumulados, uma desordem furiosa de mil coisas; e vinha um tal cheiro de ratos, queijo assado, e roupa velha, que mais parecia andar-se viajando por dentro dum artigo do senhor arqueólogo Brito Aranha (ALMEIDA, 1992, p. 9-10).

A herança do historicismo romântico põe-se ao serviço da reconstituição das vivências da cidade, marcada por ritmos mais lentos, mas de traços pitorescos. Daí resulta a visão alegórica da urbe, como se de uma velha senhora se tratasse, desgastada pelos anos, soturna pela gravidade do carácter e incapaz de resistir à decadência que o passar dos tempos implica. 
Entanto, com o montuoso do solo, a irregularidade pitoresca das casas, descortinada dos cimos, era uma confusão de brancas fachadas, tectos em chapéu de clown, varandas que iam e vinham, arborejos ictéricos e torrelas de freguesias; mas nenhum trecho de carácter, arquitectura tipo, ou atrevido zimbório, em que pousar a vista cansada de voar sobre esses bairros taciturnos. Quando ao canto de tal rua, perdido entre humildes casinholas, meio sepulto numa ladeira áspera, de repente, surge o ângulo dum velho palácio brasonado, desconforme como os mausoléus de Tebas, quadrado, derruído, singular de velhice e majestade! Os portais desdenham-se em pedra esculpida, mas instalou-se uma carvoaria no pátio; por cima, a sobreloja serve de pouco aos pobres cantores da rua, cegos simples e compostos, tamborileiros galegos, raparigolas de pandeireta, realejos com e sem macaco, fenómenos de feira hibernando ali a estação das chuvas, entretidos a digerir o próprio estômago - enfim, toda uma corte de milagres, desde o homem dos pintassilgos sábios, até ao velho malandro que vive duma úlcera pintada, e regouga limpando aos andrajos os cinco-reisinhos que lhe dão. - Sempre há gente muito porca! Lisboa que não deixara ainda o capote e lenço tradicionais, e cria em milagres, afirmando que crescia o cabelo ao Senhor dos Passos, sentia por esse tempo um forte medo de bruxas.

Conheci prédios desamparados de moradores, com má fama de residências diabólicas, que se apontavam de longe aos exorcismos das beatas. Os cães vadios, então mais numerosos que os empregados públicos, desfrutavam nonchalances que o Chiado não permitiria hoje aos seus mais imprudentes janotas. De resto, havia em poesia a especialidade dos cisnes. Ser cisne era uma destas glórias tocantes, uma destas emoções subtis, uma destas requintadas lisonjas, que só hoje têm paralelo nos laureados de Mont-Réal ("Lisboa Velha e Lisboa Nova", p. 10-11, in ALMEIDA, 1992, p. 9-22)

Mas se essa era a Lisboa de outras eras que ainda persistia nalguns quarteirões, a nova capital erguia-se em estreita simbiose com a primeira. Alargavam-se os bairros, ampliavam-se as ruas e riscavam-se largas avenidas. O conforto burguês seduzia fortemente e até parecia, ao olhar perspicaz do escritor, que se ousavam ultrapassar os sensatos limites do bom senso, desfrutando-se de um bem-estar superior às possibilidades das camadas médias da cidade:

Ardendo numa febre de grandezas, Lisboa sentira a necessidade de outras ruas, outros estilos, outros interiores: alguma coisa coerente com os ideais, os hábitos e os trabalhos da sua vida moderna. E ei-la transbordando dos 
acumulados lúgubres dos velhos bairros, Alfama, Mouraria, Estrela; partindo a cintura de muralhas num charivari de construções podres de chic; fazendo dos arrabaldes, centros; trepando aos outeiros, ou alastrando-se como um acampamento nómada, à beira do rio.

O estilo das casas ricas, perdendo o carácter pesadão, medieval, que antigamente era bom gosto entre as classes altas, e quase passava ao proprietário diplomas de fidalguia, punha agora esforços evidentes para se armar à ligeira, sem perda de distinção ou desarmonia de linhas. E apareceu a casa moderna, pelo estilo de Paris! As primeiras tentativas desagradaram. O português é naturalmente pesado, amigo do sólido, e rebelde às ligeiras coisas de arte tão maravilhosamente francesas por índole e origem. É ver os nossos paisagistas. Os nossos escritores. Os nossos poetas. Queremos na obra de arte o excesso, qualquer forma que o traduza e comprove. Em literatura, a hipérbole, um estilo atormentado de imagens e cheio de bizarras teorias. Na tela, coloridos estridentes, veemência, profusão ("Lisboa Velha e Lisboa Nova", p. 14, in ALMEIDA, 1992, p. 9-22).

A elegância vigente seguia a moda importada do estrangeiro e a identidade do gosto tipicamente português adulterava-se. $\mathrm{O}$ requinte emparceirava com o exagero e a falta de discrição. A teatralidade de interiores impunha-se e a decoração assegurava um espaço privilegiado na elaborada busca de exotismo que combatia o cosmopolitismo urbano trivializante. As residências da burguesia em ascensão transformam-se em luxuosos museus de peças invulgares, não raro misturadas com uma fancaria de cunho puramente caprichoso:

Escadas largas, com corrimões de bronze, lambrissées de mogno, sob uma cúpula em vitrail, fazem nas residências pequenos museus fantásticos e preciosos. De lance em lance, alguma estatueta suporta um globo de alabastro. Nos patamares com jarrões esvasados, espalmam-se decorativamente folhagens de avencas, glixínias, trepadeiras, fetos raros; em volta aos espelhos com molduras de ferro forjado, as heras sobem num redenho de metal - enquanto as bananeiras empenacham a boscagem das suas grandes folhas, e tufos de begónias régias, carnosas, húmidas, circuladas dum sangue rútilo, parecem corações de virgens levianas oferecendo-se ao primeiro que suba. Através dos vidros de estufas, nos maciços dos jardins e parques luxuosos, plantas que arvoram exóticos modelos de floração, como outros tantos pavilhões de revolta contra as rotineiras formas do lírio indígena, das rosas de cem folhas e dos embirrantes cravos de defunto. São os hibiscos que revoluteiam 
torcidos como cabelos em nucas ainda mal enxutas do banho - áruns de seda, perpassados duma graça virginal - rosadas orquídeas feitas de espáduas de infanta - palmeiras curtas que dir-se-iam cinzeladas em malaquite - e a sterlitzia Regina, flor de príncipes, cortada em veludo roxo e cor de laranja, rompendo de entre a hirsuta folhagem de ferro branco, com antenas de oiro e fauces de dragão chinês.

Depois lá dentro, nos gabinetes altos de vinte pés, onde o luxo é hereditário e nenhum pormenor cheira a enfatuado, lá dentro as peças da residência enfileiram a sua série de museus pessoais, tão caros à família, feitos de recordações de viagens, memórias das pessoas ausentes ou mortas, dos amores fanados, dos respeitos comovidos - tudo isso que é bugiganga e não obstante preocupa - móveis e bronzes de arte, porcelanas, velhos Sèvres, barros e marfins escultados, leques, armas, rendas, miniaturas - acessórios de bem-estar e de luxo, espargindo a vivacidade aérea das suas linhas e volutas, pousando dois dedos de loucura na vida calma do interior, e por cima inoculandonos uma sorte de nobreza, pela contemplação raciocinada de tantas coisas preciosas. Em Lisboa, já não é preciso entrar no palácio dum amador ilustre e rico, para encontrar a obra de arte como centro de adoração. Este século desceu-a dos templos e dos palácios, e pensa vulgarizá-la mais ou menos intacta, pelas residências modestas, mercê das indústrias que a reproduzem e a vulgarizam. De 34 para cá, a educação, apesar de morosa e desleixada, deu aos nossos homens refinamentos intelectuais progressivos, que fizeram dele, em política um céptico, em ciência um crente, um ateu em religião, no amor um bandido, e na arte um diletanti. Raras naturezas, plebeias mesmo, ficam hoje insensíveis ao encanto de uma fina obra trabalhada por algum artista de génio. Eis as classes burguesas cultivando o gosto, esse bom senso delicado, dizia Chénier, pelos ditames de uma inspiração já literária; visitando as exposições de quadro e as lojas de coisas antigas; indo a concertos; estimulando-se nos leilões célebres; seguindo com prazer as discussões que uma estátua, um quadro, ou tal peça de mobília provocam nos jornais; desenvolvendo, numa palavra, aptidões intuitivas de artista, tão próprias num país de sol como o nosso, colorista fatalmente, país de paisagem, que possui os trajos do Minho, as marinhas e costas do Algarve, as cantigas de trabalho do Alentejo e os cerros e castanheiras da Beira ("Lisboa Velha e Lisboa Nova", pp. 16-17, in ALMEIDA, 1992, p. 9-22).

O diletantismo afirma-se nestes ambientes como pose e o apreço pelas obras de arte procura adaptar-se ao ambiente por vezes rude da cultura portuguesa, embora autêntico, mesmo quando tal processo ocorre na capital. 
Resulta daí uma atmosfera compósita, um larzinho pequeno-burguês tépido e confortável, que se generaliza às classes médias, que o autor particulariza tomando um exemplo como caso de estudo:

Emília deliciosa num roupão de pelúcia azul com rendas brancas; o glu-glu da cafeteira fervendo na cozinha; toda a residência coberta de estofos de cores atenuadas, com bocadinhos de arte aqui e além, sobre as consoles, e verduras tenras, subindo em espirais exóticas e lânguidas, dos pequenos vasos de faiança francesa: a gata dormindo sobre um coxim do canapé - e por baixo das janelas, fundos de jardim adormecido em esponjosos vapores, na penumbra daquela noite chuviscosa de Novembro ("Roberto", p. 155, in ALMEIDA, 1992, p. 149-158)

A contrastar, afloram-se as dificuldades económicas das classes mais baixas que coabitam nos mesmos edifícios em andares superiores e com menos condições, revelando desse modo a outra face da Lisboa oitocentista. Aí se abrigam os dramas do quotidiano e se combate a dura batalha da existência, dia a dia, hora a hora, sem esperança e sem alento:

E nesse segundo andar sem cortinas nem esteiras, duramente mobilado, grosseiro de contacto, sem o convite amável dum estofo, onde as pesadas bancas vergavam ao peso de papeladas amarelentas, e baús de coiro e lavatórios de ferro arrastavam pelos cantos, entreabertos, desordenados, num desleixo fétido de hospedaria e casa de batota - nesse segundo andar tão sem conforto, ela, Albertina, iria sepultar a sua mocidade como numa cova, não recebendo, não conversando, não saindo - com a eterna paisagem do rio ante os olhos, se os alongasse - com a promiscuidade da gente ovarina, cantando-se ao sol caso os descesse ("A Verruga", p. 169, in ALMEIDA, 1992, p. 167-180).

Estes ambientes não divergiriam muito daqueles que das grandes capitais europeias chegavam, reproduzidos nas obras de uma literatura que denunciava a vida difícil de um proletariado crescente, resultante da chegada à cidade das populações que se viam obrigadas a migrar dos campos, na expectativa de melhores condições de vida. Tal fenómeno permitia por vezes alimentar às gerações mais novas dessas camadas deslocadas a ilusão de uma rápida ascensão social e provocar, como consequência, a degradação moral e ética, escondida nos andares superiores e nas mansardas dos prédios, onde se remoíam as mágoas com o desencanto e a aceitação da sina que lhes estava destinada. Por isso, os valores tradicionais começam a ser questionados e a 
velha moral a ser minada numa sociedade em que o jogo das aparências ainda se reveste de uma validade respeitável. Por isso se assiste á desmistificação de determinadas figuras e de uma visão romântica da vida:

- Isso é teórico. Nenhum homem pode amar toda a vida uma mulher. Que suplício para ambos, se assim fosse! O amor é dos primeiros tempos. Depois, a estima se encarrega de tornar felizes os dois, de companhia com os filhos, se os há. Um marido é além disso mais que um homem que nos dá beijos depois do jantar, quando o cognac se lhe vaporiza na cabeça, e a digestão lhe sobe à boca. É o procurador dos nossos interesses, o que satisfaz as nossas exigências de pequenas perdulárias, o que nos acompanha se estamos tristes, e nos aconselha se vamos tresviadas. É o nosso bom rapaz, o nosso gozo e o nosso banqueiro, aquele de quem nos podemos fiar cegamente, sem temor de burla ou descrédito. O que não vê a nossa leviandade, aprecia-o ele, do fundo do seu bom senso viril. Com espírito deve ser-nos superior, como homem não nos deve envergonhar (“A Verruga", p. 177, in ALMEIDA, 1992, p. 167-180).

Corroem-se assim, na perspectiva da mulher, as ilusões de felicidade eterna do casamento enquanto instituição fundamental da sociedade burguesa, da vida familiar institucional. Talvez como compensação, a diversão no ambiente urbano constitua um aspecto de relevo, numa atmosfera que se afirma cada vez mais hedonista. A descontracção do Passeio Público como espaço de sociabilidade, muito particularmente ao cair do dia, não obstante alguns laivos disfóricos, continuava ainda a ser apreciada, tal como acontecia no tempo de Júlio César Machado, de meados de século:

Era esta a sua hora lilás durante o dia. O barulho das ruas que reanimava a sua inanição de antigo galã derreado pelas intimidades do amor que ceia. $\mathrm{E}$ Rossio fora, lá ia tomar o sol cor de açafrão da Avenida... Naquele recinto do pressuposto luxo lisbonense, em que tudo parece alugado por uma agência de pompas fúnebres, as árvores, os bigodes, as carruagens, as sobrecasacas, o tom das luvas e o silêncio lúgubre dos janotas: naquele recinto de luxo, à hora dos trens, que popularidade a sua, tão superiormente afixada no invejoso adeus dos homens, e no sorriso afável das mulheres!- Adeus, Fantoche! - Como vai isso, Fantoche? - Olá, Fantoche! E as mamãs metendo à cara do dandy as suas filhas. As condessinhas fazendo parar, por vê-lo, as suas equipagens. Repórteres tomando nota do seu humour sobre o caso o dia. E jornalistas aprendendo o seu bote secreto, nesse jogo de esgrima dos cães, malicioso, e que tão bem recorda o jogo... de águas de Versailles ("Fantoche", p. 187, in ALMEIDA, 1992, p. 181-188) 
Ali desfilavam as vaidades humanas e se mostravam os mais variados tipos da sociedade lisboeta. Contiguamente ao Passeio Público, a Praça do Rossio era um ponto de encontro preferencial, onde todos se podiam cruzar quando assim o entendiam. Constituía o ambiente preferido da élite e o rodopio da população era notório, pelo menos em certas horas do dia:

Eram gastrálgicos de ventre alto, trinta anos fanados com primeiros pés-degalinha ao canto das órbitas; pequenos crustáceos de redacção, vilegiando na esteira das coristas da Trindade; jovens loiraços de esporas e vincos sebáceos na copa mole dos feltros; enfim, dominadores ricos, herdeiros do alto comércio, aristocratas de nariz em bec; ou glaucos militarzinhos pobres, que o rumor dos breaks elegantes, ou o trote das parelhas em voga, não deixavam resignadamente aceitar a miserável vida que levavam. A essa hora, afluía toda a cidade àquele ponto d'élite; senhoras em ranchos que voltavam para jantar, num giro preguiçoso da tarde, vestidas de escuro, com passinhos de ave, e uma gaze ruiva a meio rosto, mosqueada de negro; carros que rolavam nos seus vernizes novos, ou cavalos piafando para êxtase da mocidade garbosa e doirada. A meia ladeira, por aqui, por além, às esquinas do Seixas, nas lojas de estampas, ou no Herculano, grupos de homens estacionavam, falando em circuito, sobre a questão dos bispos e o benefício da Páscoa. E na fadiga das caras, na ansiedade dos olhos, em alguns traía-se a convulsão duma recalcada luta interior, cortada de derrotas, ou cheia de manhas e ciúmes ("A Condessa", p. 84-85, in ALMEIDA, 1992, p. 77-88)

Nesse rito de doce deambulação, a beleza das mulheres era um aspecto cada vez mais notado, pela importância que assumia a divulgação do requinte das modas parisienses, fazendo com que os homens, especialmente os desocupados, herdeiros de famílias de grávido pecúlio, enxameassem a Praça na ambição donjuanesca de um encontro mais feliz. Eles também eram agora o produto de uma educação renovada, em nada descurando uma formação cuidada e visando o sucesso nas carreiras a que se propunham:

A educação dos ginásios, a apoteose da beleza feita aos acrobatas sob o ponto de vista da força, e uma forte propaganda dos exercícios de destreza - a carreira, a caça, a equitação, o tiro ao alvo, a remagem, etc. - vão transformando para melhor o tipo dos nossos rapazes, criando corpos vigorosos, musculaturas elásticas, linhas finas e firmes, outra correcção de carácter e outra viveza de temperamento. E não se veja um efeito literário neste culto à 
beleza plástica. Cada homem que nasce necessita três coisas: ser inteligente, ser forte e ser belo. Sem inteligência ainda se é feliz. Exemplo, os adidos de Embaixada. Sem força ainda se vive. É o caso dos nossos generais. Mas sem beleza, de que serve, ó deuses, ter visto a luz? ("Lisboa Velha e Lisboa Nova”, pp. 20-21, in ALMEIDA, 1992, p. 9-22)

Entre estes, o modelo social por excelência que mais se evidencia é o do 'visconde', repositório acabado dos traços de requinte que a sociedade liberal impõe ao homem da época. Não é muito diferente o Jacinto de $A$ cidade $e$ as Serras, de queirosiana memória, em que a exagerada sofisticação produz uma espécie particular de cansaço existencial:

Encontrei outro dia o visconde. O mesmo, sabe?

A sua eterna mania consiste ainda em representar um fim de raça, que se debate com a nevrose, e se aborrece de tudo, das mulheres, dos cavalos, dos restaurantes e das viagens.

O que mais me espanta neste tipo de decadente, mais bonito do que viril, e antes efeminado do que cavalheiresco - cujos claros olhos se afogam, sob o cetim dos cílios, numa preguiça mole de oriental; e cujo sorriso em flecha, posto que húmido, me parece guardar o seu canto de mordacidade cigana, extremamente cínica e pressentida - o que mais me espanta neste decadente é a mistura de preguiça e força nervosa que vejo fundidas nele sem predomínio exclusivo daquela ou desta, e todavia colaborando em dose desigual, conforme os dias e as impulsões (“Miss Ellen”, p. 160-161, in ALMEIDA, 1992, p. 159-166)

Mas à luz desta perspectiva estetizante cada vez mais vincada, a figura da mulher aparece igualmente cada vez mais idealizada. Divulgam-se e partilham-se novos critérios estéticos, reconfiguram-se arquétipos mitológicos, num jogo crescente de sensualidade e sedução, assumindo-se uma perspectiva predominantemente masculina:

Desapareceu há muito dos salões o tipo da Vénus barbuda, Vénus porcoespinho, que espavoria os oficiais da marinha inglesa nos bailes da senhora regente. Uma raça de brancas mulheres flexíveis e altas, cabelos castanhos e bocas em flecha, beleza mais intelectual do que física, fundada na cintila histérica dos olhos, na esquisitice das mãos, nas fragilidades da cinta, passeia hoje os asfaltos da nossa bela cidade, enche os salões de concerto, faz os five oclock tea, aplaude nos teatros, revoluteia por essas praias e estações de águas - com pés quase espirituosos, dolências de espáduas, e nucas de oiro em que 
parece aninharem-se colibris de beijos. Beleza sem amplidão, convenho, sem traços salientes, de acordo, sem unidade, sem arquitectura; beleza fruste, flor dum dia, fundada nas carnes, e que uma vez fanada, como não tem transição, resvala nas peles de galinha duma velhice precoce. Mas em compensação, a sua adolescência é o que o mundo tem de mais encantador, de mais elástico, de mais destro; e elas aí vão por bandos e revoadas, as belas Dianas e Ledas, adiante das mamãs, braços dados, rindo e pipiando nos peristilos, cingindo ao busto os forros das suas sorties de bal, recompondo sobre as testas cabelitos rebeldes, lorgnando os rapazes com ares de duquesinhas à Brantôme, na íntima delícia da sua adorável frivolidade. Estas galanterias vivas de dezoito anos, ainda elançadas numa espécie de hesitação de sexo, ressumbram virgindades já provocantes, tendo nas íris raiadas a castanho e fulvo, alguma coisa da astúcia ingénua das gatinhas nubentes. E a extravagância dos vestidos, o pele-mêle das cores, a fanfarrona postura dos chapéus altíssimos de copa, aba curta e molhos de plumas mirabolantes!... o que elas desenvolvem em público, de talento cénico, graça artificiosa, espírito e adorável calinerie, é por si só um poema de sagacidade e ruse feminina ("Lisboa Velha e Lisboa Nova", p. 19-20, in ALMEIDA, 1992, pp. 9-22)

Assim se manifestava o deslumbramento, o luxo, o exibicionismo do requinte alcançado pela mulher da média e alta burguesa nos encontros sociais. A sociabilidade encontrava nas soirées um momento de eleição e a elas acorriam igualmente as figuras gradas da cultura e do jornalismo. Discutiam-se temas eruditos, questões sociais, mas também o fait divers do quotidiano com a graciosidade que o ambiente implicava:

Eram animadas as soirées do papá Borges, gente de todas as cores, monumental o bufete, política pelos cantos... Na confusão das gravatas brancas, um ou outro tipo destacava o seu tom caricatural: Joãozinho, um brasileiro que aparecera em Lisboa num estadão; o artilheiro Faustino, que viera bom do Algarve; a figura espectral do delegado Amâncio; juiz Pádua, sempre dobrado às exigências da etiqueta...

Todos estes comparsas da moda, celebridades de momento, homens de letras inéditos, sábios sob palavra de honra, ou janotas sem fortuna conhecida, faziam a grande raça eleita em que o país tinha os olhos, e donde se tiravam funcionários e generais para todas as espécies de exércitos, finança, professorado, parlamento, burocracia e jornalismo... A mor parte eram rapazes exasperados de pobreza, lutando com a vida magra das casas de hóspedes, sabendo dolorosamente o valor do dinheiro, e tentando perfurar tenazmente a 
crosta de obscurantismo, para na evidência surpreenderem posta, consulado, embaixada, comissão ricamente provida, ou o acaso dum bom casamento. E cada um tinha o seu sistema de ataque. Uma ambição ardia nos olhares, por trás dos sorrisos e das afectadas blandícias (“A Verruga”, p. 171-172, in ALMEIDA, 1992, p. 167-180).

Em alternativa a esses encontros de salão, o culto da natureza, quando o tempo mais quente e agradável o permitia, arrasta as mesmas classes para uma inebriante evasão para os campos, em passeios pelos arredores, manifestação de alegria de viver ao ar livre, e a sociabilidade algo requintada ultrapassa as portas dos salões dos palacetes. Talvez por isso, a ida às quintas dos arredores, já descrita por Júlio César Machado em meados do século, continue a desfrutar das mesmas simpatias algumas décadas mais tarde:

À entrada de Maio, o alegre bando de mundanas debandou para o remanso das quintas. É quando Lisboa perde as suas mais franzinas e graciosas figuras. Mas o convívio prosseguiu, e matinées dançantes, vestidos de cassa, com cachos de lilás nos cabelos continuaram por baixo das árvores os calafetados bailes do Inverno anterior, onde as camélias fanam aos primeiros hálitos do gás, e os veludos negros fazem luminosos os ombros nus das mulheres. Todas as manhãs, landeaux e carros de mil formas, despejavam à porta das casas de campo, burburinhos de adoráveis palradoras, chilreantes visitas que vinham de longe passar o dia, trazendo recados desta e beijos daquela, invadindo os aposentos numa chanfranafra, para despertar os dorminhocos, com ordens sem conto à cozinheira, e o laisser-aller de quem faz da vida um paraíso ("A Verruga", p. 171-172, in ALMEIDA, 1992, p. 167-180).

Apesar de a sociedade portuguesa da segunda metade de Oitocentos - e o ambiente da capital é um exemplo flagrante desse modus vivendi - se revelar particularmente austera, de valores rígidos e sóbrios, e de códigos inflexíveis, pelos relatos dos folhetins, é ainda possível reconstituir os momentos de folguedo e alegria nas vivências da cidade, muito embora, de facto, mais desfrutados pelas classes influentes.

Contudo, a meu ver e como mencionei, os aspectos mais impressionantes dos folhetins de Fialho de Almeida, quando trata de Lisboa, referem-se à passagem das horas na cidade, ao modo como os tipos que a povoam se vão sucedendo nos mesmos espaços e neles coabitam. É como se uma câmara de cinema captasse, parada, as figuras que se movimentam, entram em cena e desaparecem. Assim, o crepúsculo do fim do dia desperta no autor uma 
variada gama de sensações, que só um paralelo com o impressionismo dominante na pintura da época poderia igualmente transmitir:

Docemente veladas de nuvens, as noites vêm rápido logo ao cair das Trindades, após um curto crepúsculo, onde as primeiras brumas de Inverno se esfarrapam.

As zonas de gás mal esclarecem os escaninhos da rua - rolam as carruagens numa preguiça mole de sendeiros estafados - os cafés enchem de claridades os vidros dos seus portais - fecharam as fábricas e as modistas - e eis uma população laboriosa que se atropela e precipita, numa avidez de liberdade, resfolegando os primeiros haustos de ar enregelado. ("Roberto", p. 149, in ALMEIDA, 1992, p. 149-158).

A saída do trabalho constitui, pois, o ponto de partida para esse lento processo, progressivamente descrito, de instauração dos ritos da vida nocturna que se abate gradualmente sobre o centro da cidade. $\mathrm{O}$ bater dos sinos e a iluminação pública a gás acentuam o ambiente da hora de recolher. $\hat{E}$ a altura em que os rapazes apregoam os jornais e os cauteleiros dominam o ambiente dos largos e ruas. As lojas ainda jorram para o exterior uma claridade que anima a calçada. Carruagens deslizam.

Cinco horas, seis horas... a noite desce, e o angelus desagrega-se dos sinos, pelos ares, como uma voz de concórdia apaziguando os homens cansados de se traírem durante o dia inteiro.

Da barra vão subindo vagarosamente uns leves chuviscos: o ronronar da cidade cresce e descrimina-se em ruídos múltiplos, no côncavo da noite; e é a hora dos pequenos burgueses terem acabado de jantar, e dos estudantes ociosos colherem no acaso das ruas, a amarga e fanada flor de uma aventura. Um a um, os lampiões de gás acendem as suas luzinhas vermelhas, em fúnebres fieiras, que parece fazerem nas ruas grandes perspectivas de enterros. Os garotos apregoam jornais e os cauteleiros, cautelas: sob as árvores das praças, ao longo dos asfaltos marginais das ruas, escuros formigueiros de gente hesitam, vão e voltam, fosforentes os olhos, os gestos torturados, como se uma inquietação começasse a desorientá-los.

As lojas iluminam as suas étalages de camisas, móveis, retratos, loiças, confecções; passam os americanos como grandes bichos de conta, surdos e achatados; e nos focos de luz que escorrem das vitrines, sobre os passeios, numa inundação cruel de claridades, súbito, as figurinhas dos viandantes esclarecem-se - mulheres apressadas, cujos tacões mordem a lama, num tique 
de bonecas e de adúlteras, carvoeiros e janotas, barretes e chapéus altos - tipos diversos ruminando interesses diversos, egoísmos recônditos amortalhando, em misantropia exterior, o brasido das suas insaciáveis ambições ("De Noite", p. 125-126, in ALMEIDA, 1992, p. 125-134)

Nesse ambiente, desliza ofegante em agitado movimento a população que se apressa a recolher, na ânsia de alcançar um pouco de descanso para o corpo, depois do dia de trabalho. E o escurecer do céu acompanha esse enlanguescer da humanidade:

Já a essa hora as iluminações têm aumentado, e nas janelas das casas há moribundos brilhos discretos de candeeiros, sombras que se desfazem, correndo na brancura dos stores e das vidraças; e a gentana cresce, acotovela-se, confunde-se, apagando os cambiantes de estofos na mesma uniformidade de vultos pardacentos: e tocada de vertigens ei-la circula de roda aos quarteirões das casas, cada vez mais inquieta, cada vez mais exasperada, e como entretida nalguma extravagante ronda de funâmbulos.

De quando em quando, às esquinas dos prédios, de roda do banco de uma praça, no boqueirão de treva de um arco ou dum portal, fazem-se remoinhos bruscos de transeuntes, instantâneas paragens, como se aquelas criaturas todas andassem automáticas, desinteressadas, pedindo ao acaso da rua uma emoção.

Por cima dos prédios, sossego! O céu ganhou uma cor de nanguim lúgubre e morta, sem estrelas, zebrada com farrapos de névoa, donde goteja o tédio em pérolas letais: e os olhos que se erguem cá do fundo das ruas mosqueadas de luzeiros, contra essa escuridão terrífica dos ares, os olhos vêem os cocurutos dos prédios apagarem-se num vago, e os fios do telégrafo em pautas de música, de esquina a esquina, reduzirem vagamente, como outras tantas cordas de uma harpa, aonde em surdina vibrasse o De profundis duma raça de escravos e truões (“De Noite", p. 126, in ALMEIDA, 1992, p. 125-134)

Nesse momento, quando os contornos da realidade se transfiguram e se esperaria que a cidade aquietasse, em contrapartida, adquire um renovado alento: é como se um animal grotesco e ameaçador despertasse, com um estilo de vida muito peculiar.

Nesse corpo de monstro escamoso e fosforente, que é Lisboa de noite, feito de placas, corcovas, pernas, anquiloses, há um sistema arterial desenhado a luzes de gás, por cujos grandes vasos carroçam movimentos e vida; e um 
sistema nervoso para a repercussão das suas grandes misérias e das suas grandes dores ("De Noite", p. 128, in ALMEIDA, 1992, p. 125-134)

Depois, sucede-se outra fase do anoitecer: à componente visual, sobrepõe-se a auditiva. E compreende-se o motivo, visto que, com a escuridão, os restantes sentidos apreendem a realidade circundante com mais facilidade: ouvem-se cornetas militares nos toques a recolher, enquanto as diversões nocturnas convidam a espairecer. Os teatros abrem as portas à medida que as lojas as encerram. A 'fauna' que circula pelas ruas já é outra: costureiras, "mefistos", os clientes retardatários e o público dos espectáculos.

Oito horas, nove horas... na parada dos quartéis, as últimas cornetas tocaram melancolicamente o recolher. A multidão prossegue sempre o seu movimento espiral de roda aos quarteirões, agora mais rara, porque os teatros engoliram pelo menos um terço dos vultos que esformigavam nas ruas, à cata de pretexto para esquecer a vida e as suas agonias.

Entram os estudantes nas suas mansardas, a recoser as lições para o dia seguinte; nas tabacarias os últimos maçadores contam à pressa as últimas anedotas; e enfezaditas, com toilettes fanadas, jóias de strass e chapéus murchos, as costureiras passam de volta do serão, trotando às três e quatro, como cabritas receosas, rápidas e exangues... o seu tipo dúbio de mendigas e de cocottes, uma mancha de carmin nos beiços perversos... e os olhos alongados, mirando pelo canto das pálpebras os monsieurs seuls que estacaram no asfalto com um ar de mefistos pulhas, a remexerem nos bolsos, à passagem da caça, placas de cinco tostões que dizem tudo ("De Noite", p. 129, in ALMEIDA, 1992, p. 125-134)

A esse ritual do recolher do proletariado urbano, sucede-se, depois, a etapa em que a cidade parece invadida pela ralé frequentadora dos cafés, dos bilhares, casa de batota e prostíbulos. Anima-se uma nova face da realidade, subterrânea e vampiresca que apenas emerge nas trevas da noite. Ostenta traços individualizantes, grotescos, sintomáticos da vida 'anormal' que os anima:

Isolados, ou por pequenos grupos, a horas inflexíveis, vêem-se aqueles tresnoitados bichos surgir dos portais das casas, e entrarem e saírem dos cafés, dos bilhares, das casas de batota, prostíbulos e baiucas de aguardente, as pálpebras pisadas que um tique epileptiza, olhos de morcegos e de gatos, o passinho mole, as mãos errantes procurando apagar-se, não dar nas vistas: $\mathrm{e}$ 
eles sem voz, com um sorriso beato, descrevem parábolas de roda das coisas, com medo de tudo, numa horrível suspeita de si próprios!

Nos seus hábitos externos, na evasiva das conversas, no receio de encararem uns olhos frente a frente na sua aquiescência de opiniões, e tolerância para as chalaças duvidosas, vem toda a revelação duma conduta subterrânea e sequestrada. Alguns são pálidos, bisonhos, longos, dessimétricos de face, com uma vacuidade de espectros e de lesmas. Outros gorduchos, com apoplexia no afogamento da papada, um tom de lagosta e de ouriço-cacheiro, todos se rebolam, perorando, cocitando os ouvintes com blandícias de olhos, gestos minúsculos, e anedotas dum recorte canalha e pitoresco. $\mathrm{O}$ álcool caquetizou precocemente alguns em plena adolescência, revertendo em obesidades oleosas a nutrição que devera gastar-se na enformatura máscula do corpo e juvenilidade das formas extremadas.

São neste caso pretexto para ventres, alguns curiosos, com o feitio de melões, prenhezes, malas, balaústres, chapéus de coco - ventres aonde eles todos se recolhem, disfarçam e acastelam, sumindo pernas e braços, como as tartarugas na concha, em vendo grifo.

Em quase todos a voz faz voltar a cabeça a quem a escuta, inessexual, roufenha, com guinchos de alarme ao canto das palavras, e aqui e além de um vago mel a destilar perversões congénitas e infames ("De Noite", p. 130-131, in ALMEIDA, 1992, p. 125-134)

Nalguns casos até, é a degradação total que se manifesta através de sinais doentios de maleitas degenerativas, causadas ou adquiridas, ou de condutas pouco recomendáveis:

Nas ascendências de quase todos há fatalidades lúgubres de herança, o alcoolismo, a loucura, a paralisia geral, a pederastia, e todas as vesânias estranhas do luxo, misticismo e dissipação. Novos ainda, trazem já nas faces o seu horroroso estigma de família: a meio duma conversa lúcida de repente, um monossílabo disparata, um estremeção repentino os desorienta - ou são lacunas de memória, exasperos sem causa, frouxos de riso macabro e convulsivo, que deixam ver, por baixo da compostura exterior, a evolução da doença, corroendo esses desgraçados Pierrots do vício baixo.

Há os megalocéfalos, que parecem fugidos do Punch e da obra caricatural de Daumier, com calvícies precoces, amarelos de marfim japonês na depressão cretina das fontes e bigodes de china, com grandes guias pendentes lembrando dois ratos entretidos a lhes comer gulosamente as mucosidades do nariz. Jogaram tudo, beberam, dissiparam, conspurcaram tudo, mocidade e carácter, 
riqueza, amores leais e força de vontade: e inermes, com vestuários feitos de peças desencontradas, uma atracção os arrasta pelos gasnetes, em perímetros febris, de redor dos templos das suas antigas glórias, cuja vida eles perscrutam da sombra, pisando a lama, espreitando às portas, interrogando os que entram e os que saem, comediantes expulsos, devorados da nostalgia do tablado aonde alguma vez a multidão os proclamou um instante vencedores (“De Noite", p. 131-132, in ALMEIDA, 1992, p. 125-134)

Alinham-se nas ruas os monomaníacos dos teatros, que aguardam a saída dos actores e actrizes favoritas, deambulam antigos batoteiros, vagabundos sonhadores... Os teatros acabam e fecham, os restaurantes enchem com a clientela que procura o reconforto do estômago, circulam cocottes, "risadas e romarias aos templos de Citera..." ("De Noite", p. 133, in ALMEIDA, 1992, pp. 125-134). Batem as doze badaladas compassadas da meia-noite. As carruagens desaparecem do cenário e apenas os semabrigo ficam a vaguear sem destino. Os guardas-nocturnos exercem o seu consulado:

A polícia considera-os com suspeita e atentamente; os guardas-nocturnos não os deixam emboscar-se na sombra dos grandes portais. Eles encontramse, consultam-se, saem por uma esquina, entram pela esquina oposta, fingem que se vão, e dali a nada surgem outra vez... E estralejando os dentes com frio, jungindo os casacos ao tronco, os olhos cada vez mais fundos, a face cada vez mais lúgubre, o passo cada vez mais trôpego, tanto circulam, que acabam enfim por cair extenuados de bebedeira, de fome, de fadiga, de doença e de deboche, até que a polícia os distribui pelas cadeias, os estatela nos albergues de noite, ou os manda de presente à Misericórdia e aos hospitais.

Todos os dias a tumba carrega com miseráveis destes para a vala, e todos os dias pelas sessenta portas da cidade uma multidão de miseráveis novos acorre de todos os pontos da província, a povoar os nossos asfaltos com os mesmos monstros, que por causas idênticas chegam a contaminar-se das mesmas perversões, a constituir-se autómatos dos mesmos vícios, e a acabar por fim no mesmo lodaçal de infâmia e perversidade ("De Noite", p. 133-134, in ALMEIDA, 1992, p. 125-134)

A partir das horas mortas de meio da noite, o que anima todo aquele que vela na cidade é a marcha acelerada do relógio para o dealbar da madrugada. E tal como tinha acontecido com a queda da noite, Fialho de Almeida 
revela-se não só um profundo conhecedor das sensações de quem passa a noite em branco, como consegue transmitir com um estilo incomparável, em aguarelas de pitoresco sabor impressionista, o lento processo do amanhecer. Não obstante, a cidade adormecida proporciona de igual modo momentos de lirismo intenso aos olhos de um poeta que capta e interpreta cada detalhe sussurrante no meio do silêncio avassalador, como se a cidade de um vasto cemitério se tratasse.

Entre as duas e as quatro horas e meia da manhã, Lisboa é cruel para o noctâmbulo. Não há onde comprar um cigarro, onde engolir dois dedos de genebra, onde ler um jornal ao abrigo do frio. Fecharam já os cafés todos da cidade, os mais bem frequentados e os mais reles, desde o Tavares até ao Refilão e não abriram ainda as casas de chocolate, como o Despique, nem as tabernas aonde os operários entram, como a ginjinha do Largo de S. Domingos, ao passar para a lide, escuro ainda.

A vida é então duma vacuidade lúgubre para os que não têm casa, nem sono, nem família. Vai-se ao acaso, tropeçando de fadiga, de redor dos quarteirões, nas ruelas infames dos bairros lúgubres, sob a poeira dos varredores, à procura duma manifestação vital qualquer, vagabundo ou forno de padeiro, compreendendo enfim o sentido dessa palavra - não ter para onde ir - que tanta vez ouvimos na boca dos mendigos, e de que nunca quisemos sopesar a angústia inarrável. De roda, tudo concorre para nos esmagar a coragem, durante aquelas duas horas e meia seculares, em que os relógios não batem, e as mais simples coisas travestem contra nós aspectos agressivos. Amortalhadas de sombra, as casarias alinham duramente as suas altas fachadas sepulcrais ao longo das ruas cada vez mais extensas e desertas, que a luz enodoa de lívido, fugindo aos boqueirões dos portais com medo das facadas, e escorrendo no asfalto em tremulinas cor ocre, zebradas de sangue, em que reluzem cristais de argila e mica, como diamantes caídos das algibeiras rotas dum ladrão." (“Madrugada de Inverno", p. 189-190, in ALMEIDA, 1992, p. 189-195)

Fantasia-se, então, sobre os dramas anichados por detrás dos muros das casas e das ruas adormecidas, em cada vão de escada ou na penumbra de cada quarto sombrio. Em contrapartida, o empalidecer das estrelas permite agora começar a vislumbrar as mais desconcertantes formas concebidas pelo Criador, com as nuvens caprichosas na tela cristalina do firmamento. A vertente social, sempre presente, na denúncia dos dramas mais recônditos, alia-se na pena de Fialho de Almeida à visão de um esteta que sucumbe perante a contemplação da suprema maravilha do Universo. 
Por cima da cidade, onde a treva comenta as impotências do gás que arde cá em baixo, todo um pavor de chaminés e águas-furtadas ergue os braços, para as profundas estrelas que não empalidecem, prenunciando a aurora. É um desespero mudo, uma raiva satânica, pelos grotescos dramas que se estão epilogando àquela hora, nas barrigas de todos esses desconformes prédios sonolentos... adultérios, infanticídios, doenças incuráveis, amores hediondos, sonhos de glória, roubos de ideias e de heranças, falcatruas de todas as espécies - de que um vintemilavos só, bastaria para levar ao patíbulo os protagonistas, se acaso os Códigos punissem crimes morais, e a justiça não fosse, dentre todas as megeras públicas, a mais insolvável e sinistra criminosa. Andam-se assim léguas e léguas, e o mesmo coma que amadorna a cidade naquela apatia de sombra, emurchece na alma alcoólica dos erráticos, a flor da evocação, elísea e vaga, reconduzindo o espírito à miserável certeza de que por mais viva fantasia que se tenha, não há cintilações como as que dimanam dum lustre iluminado, nem formas como as que brotam da toilette de baile duma mulher.

Às três da noite, as últimas tipóias deixaram o paradouro das praças, fecharam no Rossio os três estancos, os polícias sumiram-se... E cada vez mais a gordurosa treva baixa do céu, em caxemiras lutuosas, monstros de tintas, nevoeiros de passagem, que vem nuverinhando da barra, e correndo para os montes, correndo, em rebanhadas lentas de pierrots. Agora, um regelo glacial trespassa as vestes dos expulsos; erguem-se as golas, as mãos ósseas entram nas mangas dos casacos - felizes dos que neste mundo ainda podem ter casacos com mangas! - e as figurinhas lívidas caquetizam-se, as caras engelham-se, tomando os tons moles do coiro novo, e eles lá vão, curvados na sombra húmida dos prédios, em cujo desvão grato lhes seria ficar ao abrigo do frio, um instantinho ("Madrugada de Inverno", p. 190, in ALMEIDA, 1992, p. 189-195)

A seguir, o gradual despertar do bulício da cidade inicia-se com os movimentos lentos e penosos dos velhos miseráveis que saem dos seus tugúrios. Levantam-se, então, figuras espectrais que deambulam, aparecem e desaparecem, em movimentos enigmáticos, aparentando pairar noutra dimensão da realidade.

Nada é terrível como encarar na sombra uma dessas fisionomias de nocturnos, obrigados a andar constantemente para não despertarem suspeitas aos guardas, inquietos, palmilhando a lama com um choc-choc de botas descosidas. Entre os mais lúgubres, há um de barbas, já velho, encorpado, que traz o casaco logo por cima da carne sem camisa, e um penante amol- 
gado na cabeça. A sua passagem na rua tem uma hora fixa, e poucas vezes ele altera o itinerário.

Cerca das três horas, vê-se aquele homem chegar aí das bandas da Avenida, atravessar o Rossio colado às casas do lado de S. Domingos, a sua barba grisalha sobre o peito, os olhos fixos, a sacola pendente, e tão absoluto silêncio nas passadas, que diríeis um espectro marchando, de cabeça direita, indiferente aos estímulos, e unicamente absorto em debater consigo um velho caso trágico de outrora.

Para qualquer ponto que siga, a postura desse homem é sempre inteiriçada, a silhouette de gentleman, um passo largo, calmo, bem estilado, e nenhuma curiosidade pelo que se passa à roda dele. Mesmo afrontado, o seu ar não desmancha, os seus olhos não fixam, a sua cabeça não se volta.

Da grande barba, gotas de orvalho pingam-lhe sobre o escorpião do esterno e das costelas: - os seus olhos dilatam-se de sono, e olham sem ver, como encandeados de estar fitando alguma refulgência de astro, misteriosa; e no gesticular macabro, na continuada disputa que ele entretém consigo próprio, sente-se o sonho absorvendo uma existência, e a razão bruxuleando entre os exasperos do dualismo que lhe desviou o cérebro talvez da sua integridade de função ("Madrugada de Inverno", p. 191, in ALMEIDA, 1992, p. 189-195)

E, tal como o toque de recolher das cornetas dos militares marca o fim da jornada, os gritos das sentinelas evadem-se na noite para além dos muros dos quartéis. A alvorada vem, depois, na caserna, agitar cada soldado que ganha forças para enfrentar o novo dia. O despertar da capoeira faz com que os galos entrem igualmente em competição aberta com o seu canto, que ainda se faz ouvir numa cidade que alberga quintais e hortejos no seu seio. De fundo, ressoa o ruído das águas do rio na ribeira.

De roda às paradas dos quartéis estridulam de quando em quando as sentinelas. É uma toada triste, com ressaibos de penas condensadas; aqueles alertas correm, reatam-se, até cingir a cidade num colar de vozidos lentos, que não lembram a guerra, mas como apelos de reses atravessam os campos, indo bater às casas das aldeias - e as velhas que adormeceram a pensar nos filhos desterrados, talvez sintam em sonhos, nesse alerta de esperança reverdecer-lhes os emurchecidos corações. Desta nostalgia participam também os galos, cujas vozes de prédio em prédio se concitam, primeiro em chamamentos isolados, depois em coros, e por último em indescritíveis charivaris. O presságio da alva como que tornou a cidade mais sonora: cada rumor toma nos ares uma intensidade viva e cristalina, que vem aos 
nossos ouvidos reforçada, como se a repercurtisse a membrana imensa dum fonógrafo. Se nos aproximamos do rio, sente-se a água ressonar em haustos preguiçosos, nos refluxos da maré que choca entre si os costados das fragatas. E para dentro do rio, a treva liquefeita, num vertiginoso movimento espiral de formas incoerentes, vai-se lentamente aquatintando aos tons de pardo, onde se lobriga já, sobre a linha de água, o ponto fraco em que há-de brilhar a pupila azul de antemanhã ("Madrugada de Inverno", p. 193-194, in ALMEIDA, 1992, p. 189-195)

É aquela altura quando começam as tarefas matinais mais comuns. O incipiente proletariado urbano lisboeta ruma aos postos de trabalho. Só os bêbados ressonam e os que velaram sucumbem ao peso do cansaço. Os últimos noctívagos recolhem, a retemperarem de dia o sono perdido.

Um sino toca a bordo: os faróis dos navios empalidecem; e enquanto nos beirais as andorinhas dão guinchos, impacientes pelo dia, começam a soar pelas calçadas os sapatorros dos primeiros homens que vão para o trabalho, fogueiros de fábricas, serradores, serventes de obras... Já a esse tempo a procissão de carroças do lixo, vindas do Aterro, começou a dispersar-se nas ruas, numa estrupida terrível de rodados: e o cascalhar da ferragem acrescenta o barulho que vai pela cidade, nesse começo de espertina que é em Lisboa, depois de quatro horas de repouso, a primeira convulsão da vida activa. Quatro horas soam. Sobre os bancos das praças, nas amuradas dos cais, os últimos boémios caíram alfim prostrados de fadiga: os bêbados calaram-se, as sentinelas dormem nas guaritas: só nos pedestais dos squares, as estátuas continuam a não desmanchar a nobreza heróica dos seus gestos. É a hora em que os jogadores desertam das batotas, e as lanternas dos médicos, das parteiras, e das casas de passe, relampagueiam de nojo pelo que ouviram e estiveram a suspeitar a noite inteira ("Madrugada de Inverno", p. 194, in ALMEIDA, 1992, p. 189-195)

A capital readquire pouco a pouco o seu esplendor natural sob o intenso e radioso brilho do sol e tudo parece voltar à normalidade para mais uma jornada de labor. $\mathrm{O}$ encanto da cidade reside precisamente nessa renovação cíclica da vida que nela se aninha.

À proporção que o gás se extingue, as ruas vão tomando assim grandes aspectos cenográficos; as casas parecem decuplicar de enormidade: as perspectivas prolongam-se em avenidas de necrópole, azul e pardo, duma fisionomia 
formidável que nos recorda Rembrandt e as gravuras antigas de água-forte. Então começa a debandada dos corvos, daqueles cenáculos sinistros em que o vício deu rendez-vous à miséria e à morte súbita. E pelas portas de escada, a medo abertas, na suspeita dos guardas-nocturnos estarem ainda levantados, lívidas cabeças espreitam, assustadiças... patas de veludo arranham por dentro as fechaduras perras dos portões... e uns após outros, como a via está livre, eles se esgueiram, os viciosos, mulheres e homens, roufenhos de álcool, soltando por ofício as últimas gargalhadas, em toilettes de baile e de cadeia, pelas bocas dos prédios, de cujas fauces trescala o bafo da cavalaria humana que vem de escoicinhar a sua torpeza, e volta co'a luz a reprimir-se, pelo terror dos regulamentos policiais.

Toca a alvorada. Uma varina passa a correr, junto de mim. Esta mulher matinal, com arrecadas de oiro e fugitiva! - A que sarjeta atiraria ela o ventre que desfez?... ("Madrugada de Inverno", p. 194-195, in ALMEIDA, 1992, p. 189-195)

E assim se retoma o ritmo do dia a dia da capital...

Nas palavras de Fialho de Almeida, Lisboa é, pois, esse pitoresco "cenário cinematográfico", à face do qual os dramas de cada habitante proporcionam infindáveis particularidades e vivências, conferindo-lhe um colorido e uma multiplicidade de aspectos, que a moldam e lhe atribuem uma fisionomia urbana peculiar.

A CARICATURA DA VIDA QUOTIDIANA DA PEQUENA BURGUESIA LISBOETA DE FIM-DE-SÉCULO

Gervásio Lobato ${ }^{3}$ é o folhetinista que mais jovem alcançou o favor do público leitor. Nas palavras de Pinheiro Chagas, a sua obra é efectivamente a comédia da vida real, não obstante nele reconhecer um seguidor de Zola, pela forma de estudo que assume, quais páginas soltas de apontamentos provenientes da carteira de um atento observador:

São [...] uns folhetins admiráveis, cheios de verdade, de fina observação, com tipos engraçadíssimos, quadros cómicos de um chiste inexcedível. [...] Aquelas figuras são todas nossas conhecidas, temo-las encontrado cem vezes na rua. A Teodolinda, o Álvaro, as meninas Pimentas, o snr. Barata, o primo noticiarista, a M. ${ }^{\text {me }}$ Proudhomme inquilina são tipos da existência contemporânea apanhados com uma verdade suprema e com um primor graciosíssimo. Os ditos do noivado, o jantar em Queluz, as cenas da casa de jogo, os episódios do conselho de família por ocasião do divórcio, as 
procissões dos Passos e do Corpo de Deus, tudo está desenhado por mão de mestre, com lápis que sabe em dois traços fixar para sempre no papel da carteira uma figura cómica ou uma cena burlesca (CHAGAS, 1911, p. XX).

No entanto, apesar de este elogio ter sido elaborado numa fase juvenil do autor em causa, o crítico não o alarga incondicionalmente a todos os âmbitos. No que se refere ao estilo, Pinheiro Chagas revela-se até um tanto reticente, muito embora valorize a sua espontaneidade:

Parece-me que por ora ainda abusa da antítese, e ainda recorre com demasiada frequência à associação de duas ideias disparatadas para tirar do embate o efeito humorístico, recurso cómico sabido e inevitável de um grande número de escritores contemporâneos; os adjectivos caro e barato encontram-se também a cada instante debaixo da sua pena, mas no meio de tudo isso que frescura juvenil de estilo! [...] Mas o que constitui sobretudo a brilhante individualidade de Gervásio Lobato, o que o distingue entre os seus contemporâneos, é a franqueza, a espontaneidade do seu estilo e do espírito, tão diversos do estilo preparado, laboriosamente arranjado, e do espírito real, mas de gestação difícil, dos seus contemporâneos (CHAGAS, 1911, p. XXII-XXIII)

Talvez por esse motivo mesmo, Pinheiro Chagas passa em revista as diferentes gerações de folhetinistas com o objectivo explícito de comprovar, numa atitude científica, mas também de nostalgia e de exaltação pro tempore acti, que a inspiração se esvai com o enfraquecimento gradual da verve literária à medida que os tempos passam ${ }^{4}$.

O quadro porventura mais impressionante das vivências urbanas que Gervásio Lobato nos legou insere-se num romance intitulado Lisboa em Camisa. Aí se reconstitui a vida de uma família pequeno burguesa, oriunda do Algarve, formada no início da diegese pelo marido de cinquenta e dois anos (à volta do qual gravita toda a primeira parte da obra) e pela esposa de dezoito, e que se instala na capital atraída pelas oportunidades que o funcionalismo público ao tempo proporcionava. $\mathrm{O}$ núcleo familiar vê-se alargado com a chegada de uma irmã do "chefe de família", viúva empedernida, e de um sobrinho infantilizado pelos códigos e normas de uma educação fraldiqueira. À sua volta gravita uma vizinhança muito peculiar, outras famílias com filhas casadoiras, desesperadas com a ideia de ficarem solteiras, tudo fazendo para o evitar. As individualidades da época também não podiam deixar de desfilar nesse mesmo ambiente e, assim, lá surgem os Conselheiros, 
de queirosiana memória, os ministros e Pares do Reino, mas também os criados explorados, meio toscos e sem qualquer polimento, os carroceiros, os 'galegos', as parteiras, enfim, toda uma galeria de figuras que constitui a sociedade acinzentada do fim-de-século lisboeta. As pequenas ambições, o desejo de ascensão social, os recalcamentos sofridos em função de uma moral implacável, tudo é exposto sob a lente da caricatura, da paródia ou da farsa, de que se alimenta a pena do autor. Os próprios nomes das personagens são sugestivos, pela dimensão caricata já no contexto da época, contribuindo, sugestivamente, para a caracterização de cada uma delas. Os títulos dos capítulos são as 'deixas' capitosas dos episódios neles incluídos, em que o ridículo se explora até ao limite e se atinge a raia do grotesco. "Os desgostos do Sr. Antunes" (LOBATO, 1988, p. 7-14) denunciam as dificuldades em procriar; "A aurora da liberdade" (LOBATO, 1988, p. 15-30) reconstitui os festejos cívicos da sociedade liberal; os detalhes na preparação do baptizado do ansiado herdeiro recheiam capítulos como "A véspera do grande dia" (LOBATO, 1988, p. 31-39) ou a "O nome do padrinho" (LOBATO, 1988, p. 40-48); a cerimónia preenche "A ida para a igreja" (LOBATO, 1988, p. 49-57) e "O baptismo de Moisés" (LOBATO, 1988, p. 58-67); a parte social do evento é explorada (e desmontada, consequentemente, pelo olho clínico do autor) em "Antes do jantar" (LOBATO, 1988, pp. 68-75), "A vitela do baptizado" (LOBATO, 1988, p. 76-86), "O fim do jantar" (LOBATO, 1988, pp. 87-95) e "A “soirée» do baptizado" (LOBATO, 1988, p. 96-107); o rescaldo da festa surge nos apontamentos sociais que se sucedem, em "O chapéu do Dr. Fromigal" (LOBATO, 1988, p. 108-119), "A “soirée masquée” do Conselheiro" (LOBATO, 1988, p. 120-130) e "O veado real" (LOBATO, 1988, p. 131-137).

Tudo faz crer que a obra tivesse obtido um verdadeiro sucesso, visto que, de imediato, surge uma segunda parte com as mesmas personagens. A matéria agora em causa, à volta da qual tudo gravita, incide sobre as 'distracções decentes' dos momentos de lazer, muito particularmente o papel do teatro neste contexto familiar - uma caricatura do théâtre intime, tão da preferência da época, aqui sujeito a todas as limitações de espaço e das próprias personagens que nele participam e representam outras figuras ainda mais inconsistentes. Tudo acaba deturpado, alcançando-se como resultado final o fiasco do desenlace. No meio do enredo, abordam-se os encontros amorosos das referidas meninas casadoiras com os pretendentes, os casamentos assim alcançados e até as separações que se sucedem. As primeiras dificuldades surgem logo com "A escolha da peça" (LOBATO, 1988, p. 141148) e a selecção dos actores para os papéis em causa, em "A distribuição do "Pedro"” (LOBATO, 1988, p. 149-156); "O primeiro ensaio" (LOBATO, 
1988, p. 157-164) revela já a incapacidade generalizada de representar, mas que estava longe de ser reconhecida, tudo sendo solucionado na medida do possível nos "Ensaios do "Pedro"” (LOBATO, 1988, p. 165-171); "Uma cena inesperada" (LOBATO, 1988, p. 172-179) e "Uma nova actriz. O ensaio geral" (LOBATO, 1988, p. 180-186) remetem para as soluções encontradas, para que se resolvessem as insuficiências sentidas; "Dos efeitos do drama. O «Pedro" nas Secretarias de Estado e em casa do Justino" (LOBATO, 1988, p. 187191) aborda a sensação social causada pelo evento nos ambientes em que as personagens se movimentam; "O ensaio geral" (LOBATO, 1988, p. 192-198) e "A grande noite" (LOBATO, 1988, p. 199-215) tratam especificamente dos momentos 'apoteóticos'; "O epílogo da récita popular" (LOBATO, 1988, p. 216-222) arredonda a acção e apresenta o rescaldo final.

O modo vivaz como Gervásio Lobato descreve e reconstitui os ambientes, as personagens, a respectiva maneira de falar, chegando a apresentar episódios completos em discurso directo e aplicando ao romance as técnicas do drama, que domina na perfeição, tornam esta obra uma acutilante paródia aos ambientes reservados da vida pequeno-burguesa, pejados de limitações contínuas e constantes.

Por outro lado, não deixa de ser curioso verificar também que Lisboa em Camisa é uma reelaboração ficcional dos episódios e temas que o autor abordava em simultâneo nos folhetins destinados à imprensa contemporânea. A função social do teatro na Lisboa de fim-de-século, por exemplo, é objecto de análise no folhetim intitulado "O Romance de M. ${ }^{\text {elle }}$ Caprice", onde Gervásio Lobato é levado a afirmar:

O romance, o drama, a comedia estão cá fora, sentam-se nos camarotes, passeiam nos corredores, agitam-se por detraz do pano, complicam-se nos tribunaes, amadurecem nas cadêas.

É mais interessante conversar do que ver peças: nos entre-actos é que está a

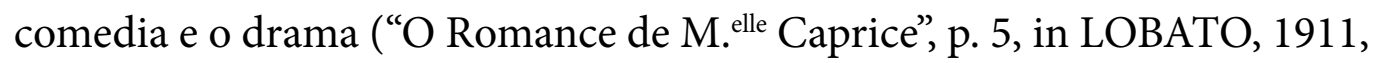
p. 3-12)

Noutro romance de vastas dimensões, verdadeiro produto do folhetim-série, de que acima falámos, reunido depois em seis volumes, Os Invisíveis de Lisboa (LOBATO, 1886-1887), volta a tratar do teatro, desta vez de ópera, logo no capítulo I do Volume II, intitulado precisamente " Uma récita no theatro S. Carlos" (LOBATO, Vol. II, 1886, pp. 5-14). E à semelhança do modo como Júlio César Machado a esse tema associa a figura da actriz e da bailarina, também Gervásio Lobato narra "A história de uma bailarina" (LOBATO, 
Vol. II, 1886, pp. 36-71) no Capítulo IV do mesmo volume. Depois, alarga o âmbito dos espécimes humanos analisados e aborda as ocupações sociais das diferentes classes da cidade: "O almoço do Conselheiro" (LOBATO, Vol. VI, 1887, pp. 334-341) surge no capítulo L do Volume VI; "O baile masqué" (LOBATO, Vol. IV, 1887, pp. 92-110), no capítulo IX do Volume IV; e "A feira de Belém" (LOBATO, Vol. V, 1887, pp. 5-9) no capítulo I do Volume V. Nessa obra, junta a esse panorama social dois tipos de figuras pitorescas da época: "Um empresário hábil" (LOBATO, Vol. V, 1887, pp. 10-15), no capítulo II do Volume V, e "Salteadores de Estrada" (LOBATO, Vol. IV, 1887, pp. 285-289) no capítulo XXXVIII do Volume IV.

No entanto, a sua obra não é apenas o repisar de caminhos abertos pelos seus antecessores no uso da pena; Gervásio Lobato regista o que o cerca com rigor e transmite os hábitos próprios do seu tempo com a objectividade de uma câmara fotográfica, captando os ângulos porventura mais caricatos. Por exemplo, no verão, quando o calor aperta, a cidade despovoa-se durante o dia e a população apenas ousa sair ao entardecer, a apanhar o ar fresco, ou em busca de lugares arejados e agradáveis. Os jardins e parques espalhados pela cidade são a alternativa para aqueles que não podem fugir para os arredores. As «senhoras» não se atrevem a sair de casa e apenas as mães e as tias são arrastadas pelas "ternas meninas enamoradas" à cata do seu derriço, que ali se cruzam com as cocottes de profissão:

Os Recreios, o sitio mais central e mais illuminado, é o passeio dos namoros legais que tem o seu ideal embrulhado religiosamente na estola do coadjutor da freguezia, dos amores civis e francos que não se importam com a igreja, nem com o mundo, e das cocottes hespanholas, cheias de pó d’arroz e vazias de espírito, que vão alli à procura d'aventuras rendosas, mediante o sacrifício de ouvirem cantar os seus compatriotas (“O Verão", p. 96, in LOBATO, 1911, p. 93-103)

Perante o reconhecimento de tal hábito e avaliada a sua importância socialmente pertinente, procede-se à enumeração dos jardins e parques mais visitados, tratando-se de forma burlesca os espaços do Passeio Público, do Campo Grande, da Praça do Príncipe Real à Patriarcal - já com clubes nocturnos frequentados por um público bem heterogéneo -, a Lage ou o Campo de Sant'Ana. É, no entanto, o Largo de S. Pedro de Alcântara que mais tonalidades poéticas desperta no autor:

Nas noites de lua é d'um effeito magico, o panorama que se desenrola aos pés d'esse formoso parque, o encanto dos estrangeiros que veem a Lisboa. Pois 
não obstante a poesia suave d'esse sitio, não florescem ahi o amor platónico, as paixões ideais.

N'aquelles bancos, mais bem alinhados que os nossos soldados em dias de parada, vêem-se ao anoitecer, aos centos, casaes amorosos, arrulhando, estreitamente unidos e de mãos enlaçadas, as estrophes sensuaes dos poemas de Cythera.

Depois, á proporção que a noite vai fazendo brilhar mais o gaz dos candieiros, afastam-se sempre unidos e conversando baixinho, perdem-se naquella grande rede de travessas e ruas do velho Bairro Alto. [...] De hora para hora, o publico d'aquelle passeio vai baixando como as heroínas de Goncourt e de Zola, até que á 1 ou 2 horas da noite, aquelles bancos se transformam em leitos, e a alameda n'um vasto dormitório de vadios, apesar da vigilância da policia, que anda a acordar todos, mas que, quando acorda o último, já o primeiro está outra vez a dormir (“O Verão", p. 98-99, in LOBATO, 1911, p. 93-103).

E, se o tratamento literário da multidão inspira a pena do autor, não admira que, noutras ocasiões, sejam as celebrações religiosas que façam vibrar de modo mais intenso a sua sensibilidade. A Semana Santa é, pois, um desses momentos em que a cidade exterioriza a sua devoção e religiosidade. $\mathrm{Na}$ crónica que traz precisamente esse mesmo título, o autor confessa:

Lisboa toda, vestida de preto, refugiava-se, do isolamento cá de fora, nas igrejas cheias dos melancólicos cânticos litúrgicos, e dos aromas acres do rosmaninho (“A Semana Santa”, p. 16, in LOBATO, 1911, p. 13-20).

E, a partir da enumeração do cenário criado, começa a enumeração dos detalhes que evidenciam a virulência com que este folhetinista desmonta e caricatura os costumes e usos da sociedade do seu tempo, denunciando a hipocrisia inconsciente ou consciente de cada interveniente no palco das vaidades humanas.

A 'Lisboa' de Gervásio Lobato era, por conseguinte, uma cidade que ainda preservava traços do passado, aliás como Fialho de Almeida acentua, mas que gradualmente se moderniza e esforça por acompanhar o ritmo das capitais europeias, modernas e desenvolvidas, com ritmos cada vez mais acelerados e com uma vasta gama de tipos sociais emergentes, aumentando consideravelmente o número dos desprotegidos da sorte. Era, afinal de contas, o retrato do estado da nação e que Cesário Verde também retratava na sua poesia... 


\section{CONCLUSÃO}

Os folhetins de Fialho de Almeida e de Gervásio Lobato, assim como os da sua geração, inspirados na caricatura de uma sociedade em vias de se precipitar no abismo do fim de uma época, da queda da monarquia e dos valores por ela representados, bem podem ser vistos como textos narrativos inconclusos, uma espécie de composições sempre em vias de desactualização perante a realidade que abordam, mas sempre com a actualidade premente de quem neles pretende fixar o momento de um mundo em constante actualização. Consciente de que, afinal, o quadro e as figuras tratadas pertencem às coordenadas específicas de uma época que, ameaçada pelo seu desaparecimento iminente, despertam a simpatia e uma dada nostalgia, cada leitor é arrebatado pela especificidade do pormenor, pelo fascínio do pitoresco e pelo deleite do humor aplicado em cada situação. Talvez por esse mesmo motivo, a 'Lisboa de outras eras' continue a despertar a simpatia das novas gerações: mais cedo ou mais tarde, elas acabam por descobrir e reencontrar essa imagem feiticeira de uma cidade que, apesar de decadente, se procura renovar, preservando o ambiente castiço que marca a sua identidade.

\section{UNFINISHED NARRATIVES:THE FEUILLETONISTS' IMAGE OF LISBON IN THE END OF THE Nineteenth CENTURy (Fialho de Almeida ANd Gervásio Lobato)}

AвstRACT: The image of Lisbon, that can be caught from literary descriptions of the urban life included in the fin-de-siêcle feuilletons, may achieve not only the dismantlement of the codes of the social dominant values, but also a poetic vision of the town, capital city of a decadent Kingdom and Empire, without any chance of accompanying the rhythm of the progress of the great European capital cities. Through the analysis of different kinds of feuilletons, by Fialho de Almeida and Gervásio Lobato, the main aspects that impressed the authors and, consequently, the readers of the time were shown, at the same time that it was tried to notice how their texts can be inserted in a literary tradition that counts with names, so well known as Júlio César Machado, in the Portuguese context.

Keywords: Feuilleton, literary town images, Fialho de Almeida, Gervásio Lobato, Fin-de-siècle.

\section{NOTAS}

1 Para uma distinção mais clara e esclarecedora entre o folhetim e a crónica, consulte-se a obra de referência nesta matéria da autoria de Ernesto Rodrigues 
(Mágico Folhetim, Literatura e Jornalismo em Portugal. Lisboa: Editorial Notícias, 1998), em que delineia os traços metafolhetinescos, a pp. 283-284, e apresenta uma síntese crítica sobre o conceito de crónica, a pp. 292-293.

2 José Valentim Fialho de Almeida nasceu em Vila de Frades, no Alentejo, em 1857, e morreu em Cuba, igualmente no Alentejo, em 1911. Em 1866, deslocase para Lisboa, onde conclui os estudos elementares e, depois de atribulações várias, acaba por se formar em Medicina. A sua actividade literária desenvolve-se sobretudo a partir de 1881, data em que publica o primeiro volume de Contos. Sobre este autor vejam-se: ROCHA, 1939-1940; PIMPÃO, 1944; CASTELOBRANCO, in O Ocidente, Vol. VII; CASTRO, 1960; LOPES, 1987; BERNARDES, 1995, col. 159-163; BERNARDES, 2001, pp. 293-308.

3 Gervásio Lobato nasceu em Lisboa em 1850 e aí vem a falecer em 1895. Além de uma notável actividade como folhetinista, a ele se deve a revitalização da farsa, compondo um número considerável de peças de teatro, ao tempo muito aclamadas, óperas cómicas, teatro de revista, a par de alguns romances. Pelo facto, o interesse pela obra de Gervásio Lobato revela-se mais na área dos estudos teatrais, como se atesta pela bibliografia referenciada em OLIVEIRA, 1999, col. 207-208.

4 Cf. Chagas (1911, p. XXIII): "Enquanto os bons ditos de Júlio Machado, de Ricardo Guimarães, de Tomás de Carvalho, de Bulhão Pato se expandiam em caudalosa torrente, coulaient de source, saltavam dos lábios como a espuma do champagne do gargalo da garrafa, os bons ditos dos homens de espírito da geração nova saem-lhes mastigados e remastigados da boca, vêm lentamente, puxados com saca-rolhas $[\ldots]$..”

\section{REFERÊNCIAS}

ALMEIDA, Fialho de. Lisboa Galante - Episódios e Aspectos da Cidade. Lisboa: Círculo de Leitores, 1992.

BERNARDES, José Augusto Cardoso. Almeida, José Valentim Fialho de. In: Biblos. Enciclopédia Verbo das Literaturas de Língua Portuguesa. Lisboa: 1995, col. 159-163, v. I.

BERNARDES, José Augusto Cardoso. Fialho de Almeida: uma estética de tensões. In: História da Literatura Portuguesa. V. V: O realismo e o naturalismo. Lisboa: Alfa, 2001, p. 293-308.

CASTELO-BRANCO, Fernando. Fialho de Almeida: um Caso de Ressentimento. In: O Ocidente, V. VII.

CASTRO, Aníbal Pinto de. Balzac e Fialho de Almeida. In: CASTRO, A. P.. Balzac em Portugal. Coimbra: Faculdade de Letras da Universidade, 1960.

CHAGAS, Pinheiro, "Prólogo" a LOBATO, Gervásio, A Comedia de Lisboa, Porto: 
Livraria Chardron, de Lello \& Irmão Editores, 1911, p. V- XXV.

Distrito de Évora, n. 1, 6-1-1867.

Distrito de Évora, n. 5, 20-1-1867.

FERRO, Manuel. Narrativas inconclusas: Vislumbres de Lisboa no romance-folhetim de meados do Séc. XIX (Lisboa de Ontem, de Júlio César Machado). In: FERRO, Manuel; MENEZES, Marcos Antonio; RIBEIRO, Maria Aparecida; SERPA, Elio Cantalício et al .(Org.). Narrativas da Modernidade: história, memória e literatura. Uberlândia: Ed. da EDUFU; Coimbra: Faculdade de Letras, 2011.

LOBATO, Gervásio. A Comédia de Lisboa. Porto: Livraria Chardron, de Lello \& Irmão Editores, 1911;

LOBATO, Gervásio. Os Invisíveis de Lisboa. Lisboa: David Corazzi Editor, 1886-1887 (Vol. I, II e III: 1886; V. IV, V e VI: 1887).

LOBATO, Gervásio. Lisboa em Camisa. Lisboa: Círculo de Leitores, 1988.

LOPES, Óscar. Fialho, In: LOPES, O.. Entre Fialho e Nemésio. Estudos de Literatura Portuguesa Contemporânea. V. 1. Lisboa: IN-CM, 1987.

MACHADO, Júlio César. A Vida em Lisboa. Romance contemporâneo. Edição de Américo A. Lindeza Diogo. Braga-Coimbra: Angelus Novus Editora, 1999.

OLIVEIRA, Fernando Matos. Lobato, Gervásio Jorge Gonçalves. In: Biblos. Enciclopédia Verbo das Literaturas de Língua Portuguesa. V. III. Lisboa: Verbo,1999.

PIMPÃO, Álvaro Júlio da Costa. Fialho. Coimbra: Universidade de Coimbra, 1944. O Recreio. Revista semanal literária e charadística. 2. ${ }^{a}$ Série (16-8-1886/7-2-1887), n. ${ }^{\circ} 4,6-9-1886$.

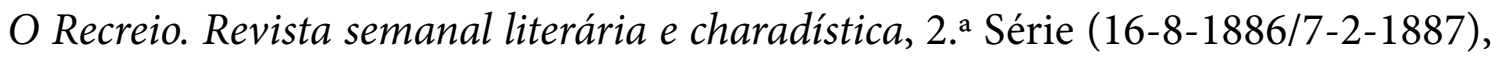
n. 11, 25-10-1886.

ROCHA, Andrée Crabbé. "Fialho de Almeida", in Revista de Portugal, n. 8 e 9, 1939-1940.

RODRIGUES, Ernesto. Mágico Folhetim. Literatura e Jornalismo em Portugal. Lisboa: Editorial Notícias, 1998.

RODRIGUES, Ernesto. Crónica Jornalística. Século XIX. Lisboa: Círculo de Leitores, 2003.

A Voz de Setembro, 29-6-1865. 